\title{
Control, cohesion and consumption: constructing young people through participation and citizenship
}

By Rachel Ashcroft (Goldsmiths, University of London)

This article examines participation as a 'discursive fact'. Using the framework of Foucault, it explores the importance of participation and citizenship as 'ordering concepts' in the New Labour project. Moreover, it argues that participation is part of a wider discourse of control, cohesion, and consumption. By de-politicising participation, New Labour serves to enhance its own legitimacy. This is the logical outcome of government as systems of thought and action. Youth and community practitioners also objectify youth, exercising similar discursive power in their own work. Putting participation into practice thus presents a challenge for workers, as they are required to recognise their power and to exercise it in a reflexive way.

\section{Introduction: 'participation'}

'Participation' is a term familiar to practitioners, policymakers and anthropologists alike. Currently 'en vogue' in the United Kingdom and overseas, it is increasingly incorporated into developmental work with young people. Yet equally prolific are the critiques from practitioners and theorists, emphasising the potential for participation to be used as a benign form of social control. As Cooke and Kothari (2001:1) note, conversations with practitioners often express 'mildly humorous cynicism'. This article examines 'participation' as a discourse in the Foucauldian sense: as a 'discursive fact', with concrete manifestations in circulations of power and human action (Foucault 1979a:11). Using the youth policies of New Labour (the current UK government) as a contemporary example, I will explore the impact of participation as a discourse, alluding to Foucault's concept of government as a 'problematising activity' (Inda 2005:8).

Rather than focusing on defining 'good' and 'genuine' participation, this article considers how participation workers can resolve the conflict between participation as empowerment and control. This concerns all those working in the field of informal education and 'empowerment', since the status as 'worker' implies a power relationship with practical implications. The article is largely a literature review, which is informed and shaped by my role as a Youth Participation Worker within local government in Croydon, just outside London. Whilst this piece is situated in a UK policy context, the objectification and control of young people is not limited to Britain, and has wider implications.

\section{Historical background}

'Participation' (literal meaning: 'the act of taking part') is a time-honoured concept. Henkel and Stirrat (2001:172) trace the concept back to the Reformation, when 
participation in religious life became a moral imperative as a response to God's grace. Community participation grew during the 1970 s, underpinned by the increasing union organisation and grassroots political campaigns taking hold (Taylor 1995:99). Consequently, participation (as involvement in public planning and decision-making) was incorporated into the state machinery as a means of avoiding public confrontation (Smith 1981b:6). Although frequently conceived as having a share in decision-making (ibid:13), at its most idealistic participation can mean 'sharing power' and enabling change (Commission on Poverty, Participation and Power 2000:18).

Participation as a form of social (and political) education has been emphasised with youth work; it is proclaimed as a means of developing young people's critical awareness of the world around them (Jeffs and Smith 1998:60). Personal (by)products include increased self-confidence, social skills and formative experiences. Moreover, participation has been a suggested solution to repeated public concerns of democratic deficit. A survey of youth political awareness in the 1970s discovered widespread apathy in response to public affairs, and political education was recommended as a remedy (Fahmy 2003:13).

In the youth work context, 'the idea of participation has a long ... pedigree but its potential has rarely been realised' (Smith 1987b:13). The Albemarle Report (Ministry of Education 1960:\$188) cited young people as the 'fourth partner' in youth provision, envisaging them as stakeholders with a right to influence decision-making procedures. Twenty years later, concerns were raised in the 'Thomson Report' (DfES 1982) that participation should mean more than just taking part. It pressed for 'young people and their communities having a greater hand in the operation and control of the service, and ... the service being in some senses ultimately accountable to them' (Smith 1987b:13). Making the ideals become a reality has remained a challenge for practitioners.

In a global development context, 'participatory' approaches have emerged, which involve local people in social and economic development initiatives. Methodologies such as PRA (participatory rural appraisal) and PLA (participatory learning and action) have subsequently been re-moulded as 'stakeholder involvement' and 'bottom-up approaches' within Europe, and used to tackle political and economic problems (Flower et al. 2000:15). Since 1997, participation has been absorbed into New Labour's broader concerns with tackling anti-social behaviour and social exclusion in the UK.

Development critiques notwithstanding, even within UK youth and community work discussions about what participation really is, and how to make it work, have always been present in the background. A 1985 conference on participation focused on 'the need for clearer statements about what (the youth service) meant by participation, what practical steps it was taking to implement it, and how it would assess the outcome' (Smith 1987a:4). These discussions continue; indeed, Youth Matters, a government Green Paper published in 2005, has sparked debate among practitioners about the conceptions of participation and involvement within it (Oliver 2005:39).

\section{The power to define}

As a historical overview illustrates, the meaning of 'participation' has evolved over time and in different contexts. Since 'participation' has no over-riding value in itself, the definitions and values attached to it give it its force (Smith 1981a:ix). As an 
ambiguous term, 'it can be passive, consultative, bought, interactive or mobilising. It depends what we want from a situation' (Pretty 2003:171). 'Participation' can be supported by mutually incompatible interests (Smith 1981b:8).

At its core are issues of power: 'all definitions of participation have one thing in common; they express (or assume) a relationship between those with the power to take decisions and those who ought to have a right to influence them' (Smith 1981b:16). As Foucault (1980:89) claims, power is not a fixed, zero-sum commodity; it is 'neither given, nor exchanged, nor recovered, but rather exercised ... in action'. Defining meaning can therefore involve 'pitched battles ... when systems of meaning are created and enforced ... by groups with the most power' (Yelvington 1996:329). Definition of terms (and corresponding practice) is a key site of negotiation, and discourse is therefore a political commodity (Gordon 1980:245).

The ambiguity intrinsic to the language of 'empowerment' or 'participation' can present an attractive cover that screens off power relations, masking the intention for power differentials to be maintained, and even enhanced (James 1999:18). Indeed, 'as participation is about power and the control of power is surrounded by mystification ... most participation that the local authority offers of its own volition is tokenism' (Smith 1981b:17). This presents a dilemma for practitioners, if the guise of participation is being used as a public relations exercise, or as a covert assertion of control. Conflicts of interest can occur between practitioner goals and the definitions of the employing organisation. For a participation worker, taking young people to 'adult meetings' risks the embarrassment of them being patronised, ignored, or talked over. I have witnessed young people sharing their opinions and then being argued with by adults in positions of authority who supposedly want to hear 'youth views'. The worker is left wondering who actually benefits from such interactions.

The caveat is that definitions do not pre-determine outcomes; people are not power's 'inert or consenting target; they are also ... the element of its articulation' (Foucault 1980:98). Ambiguity and agency open up the continual possibility for re-definition (James 1999:18). Authoritative bodies are not monoliths, but are composed of individuals with differing attitudes. Indeed, participation work depends on the support of committed individuals in positions of authority (Geddes and Rust 2000:54).

\section{Discourse and ideology: introductory remarks}

If the idea of participation is so flexible, the question remains: What are youth and community workers trying to achieve with youth participation, and what are the best methods of achieving those aims?

Many youth and community practitioners are critical of New Labour's concept of participation (Young 2005:74), alongside general assumptions that participation is good per se (Nelson and Wright 1995:2). Participation can encourage the reassertion of power by dominant groups, or aim to correct deviant behaviour (Kothari 2001:142). In a global development context, it can integrate people into political, economic and ideological structures that leave them with less control to challenge these structures (Henkel and Stirrat 2001:183).

Nevertheless, internal critiques can legitimise the participation project rather than overtly challenge it (Cooke and Kothari 2001:7). Foucault (1979a:11) argues that conflicting arguments are mutually reinforcing of the principle. Focusing on best practice can obscure the impact of participation as an ideological and discursive force. 
Rather than debating differing definitions of 'real' participation (located inside the discursive fact), we must look outside the discursive fact and question why participation is spoken about, who speaks, and how this discourse penetrates human action (ibid). This means examining participation as an 'organising concept' that 'presupposes a central unquestionable value' (Ferguson 1990:xiii).

As the previous section notes, organising concepts pre-suppose power, and creating or maintaining hegemonic discourse is a key function of government. Indeed, in Foucauldian analyses government is often defined as 'systematic ways of thinking and acting that aim to shape, regulate or manage the comportment of others' (Inda 2005:1). As Ferguson (1990:xiv) observes of development institutions in Lesotho, they 'generate their own form of discourse, and this discourse ... constructs Lesotho as a particular ... object of knowledge'. The power of government lies in its ability to create ordering systems of knowledge that render reality understandable in such a way that it is governable (ibid:1).

Moreover, government is a 'problematising' activity, as systems of knowledge both define and solve problems (Inda 2005:8). Governing discourses exercise power, providing the object and the justification for rule: 'manifold relations of power which ... constitute the social body ... cannot themselves be established, consolidated or implemented without the production, accumulation, circulation and functioning of a discourse' (Foucault 1980:93). Foucault's discussion of prison institutions emphasises the importance of hegemonic discourses in constructing truth and creating legitimacy: 'one has the impression that is of such utility, is needed so urgently ... that it does not even need to seek a theoretical justification' (ibid:25).

\section{Control}

Everyone can change - if people who need help will not take it, we will make them. (Blair 2006:1)

Former Prime Minister Tony Blair's Labour government built on the preceding government's ideological stance towards the economy, society, and youth, and this stance has been continued under the present administration. Young people are currently predominantly portrayed (within government policy and the media) as antisocial, alienated from education, employment, and 'positive activities', or politically apathetic. The problematisation of youth informs policy and contributes to their social exclusion, justifying extreme measures to control their subversive potential (Jeffs and Smith 1998:45).

Moreover, the wider New Labour project emphasises personal responsibility for social problems (many of which affect young people). The 'social exclusion' discourse can serve to internalise social problems as 'personal deficiency' (Adams 2003:27). Taking no account of social or educational inequality, New Labour re-shapes the social contract, abdicating responsibility. Powerlessness and low self esteem can be identified as 'apathy' by those in authority (Commission on Poverty, Participation, and Power 2000:32). Moreover, by 'deliberately exploiting popular tensions ... playing directly on fear and prejudice', the government endorses and justifies 'disproportionate public and policy responses' in relation to youth (Davies 2005b:6).

The preoccupation with 'anti-social behaviour' illustrates the government's construction of a youth crisis and a corresponding response. This 'new authoritarianism' (Jeffs and Smith 1998:46) has birthed a strategy that is increasingly 
inflexible and ruthless (Davies 2005b:3). The National Youth Agency has expressed concerns that 'young people are demonised by ... the community and castigated as the cause of problems' (National Youth Agency 2006:21). New Labour has established both anti-social behaviour legislation (Home Office 2003) and a Respect Action Plan (Home Office 2006). These are not purely youth policies. Yet most politicians (and, correspondingly, the media) focus on the youth aspects (Lloyd 2006:9). This is reinforced by the fact that $60 \%$ of ASBOs (anti-social behaviour orders) are given to youth (Pollard 2003). Young people do commit crimes, but the blanket problematisation of young people justifies measures that circumnavigate the legal system and heighten control over young people's lives.

Political apathy is another dimension to the 'problem' of youth present in New Labour discourse. 'Facts' such as voting figures are used as evidence of 'young people's frivolity, cynicism, and underlying moral irresponsibility' (Fahmy 2003:2). The media promotes an image of young people as 'politically alienated, apathetic and selfinterested' (ibid). Political apathy is tied to New Labour's emphasis on personal responsibility, reframing citizenship as a duty rather than a right (cf. France 1996:28). Youth Matters, the government Green Paper published in 2005 (DfES 2005b), emphasises responsibilities over rights, and 'leans heavily towards the control and conditionality side of the entitlement equation' (Merton 2005:33). The paper claims that young people are expected to 'appreciate and respect the opportunities available to them' (DfES 2005b:4). Moreover, it states that young people's 'receipt of services should not be seen as an unconditional benefit' (DfES 2005b:16). The welfare approach is increasingly overshadowed by an emphasis on control and culpability.

Problematising young people is rooted in the symbolic importance of age, and the 'myth of transition' (Mizen 2004:5). The British concept of 'youth' is underpinned (and justified) by an emphasis on age. It is also rooted in 'the changing and unequal political transactions of the industrial capitalist order' (ibid:7). The illogical fashion in which rights and responsibilities are granted confuses the status of young people, and fuels the assumption that entitlements complete the journey from childhood to 'full' adulthood (Wulff 1995:11). The construction of young people as 'incomplete adults' justifies the control of their development (ibid). Jeffs (1997:154) argues that discourses of deviant and anti-social behaviour arise from 'respectable fears' that underclass youth need regulating to pull them out of criminal activity, sexuality, and laziness. Likewise, New Labour discourse reflects middle class concerns about respectability and 'decency' (cf. the Respect Action Plan; Home Office 2006:3). The role of youth work is to provide structured (and controlled) leisure opportunities to divert young people at risk of 'contamination' (Jeffs 1997:155).

As Jeffs illustrates, youth work is not exempt from moral panic and problematising young people. The modern concept of the Youth Service emerged from concerns about the moral and social behaviour of young people in wartime Britain (Eyres 2005:28). Similarly, the Albemarle era was born out of the discourses of 'problem' youth. In order to justify their existence, youth officers have echoed (and reinforced) these moralised discourses to secure funding and legitimacy. With increasing competition for funds, youth organisations risk emphasising 'the dangers posed by unmonitored youth as well as the failings and inadequacies of young people' (Jeffs and Smith 1998:48). There is currently a lot of government funding for projects working with 'NEET' (not in education, employment or training) young people. One girl engaged in my participation project is an ex-offender, and NEET. On the one hand, her recent involvement helping with a disabilities project is making a massive 
impact on young people's lives. However, her NEET status is still frequently trumped as proof that our service is working with 'hard to reach' young people. As a practitioner I am guilty of emphasising her NEET status over and above all her other positive contributions. Even when I chose to talk primarily of her volunteer work, the fact that she is NEET adds force to her achievements.

As a time of liminality between dependence and independence, 'youth' has disruptive and hopeful connotations. Youth Matters represents young people 'as both society's future and a threat to its stability' (Wolfe 2005:62). The government response to this dilemma aims to control the transition, and to 'reorganise the lives of the young more fully according to the dictates of New Labour's political strategy of "progressive competitiveness", (Mizen 2004:177). This expresses Foucault's concept of governing as 'intimately involved in making modern subjects', moulding people's behaviour into certain accepted modes (Inda 2005:10).

\section{Cohesion: 'a modern culture of respect'}

The challenge is to create, and, where needed, enforce a modern culture of respect which the majority of people want. (Home Office 2006:3)

The crux of the New Labour project is the construction and reification of 'the vision of the Britain that we all want' (Blair 2006:1), and one emblem is 'social cohesion'. As with the negative discourses on youth, this rhetoric is also 'intertwined with specific regimes of truth' (Inda 2005:8). Definitions of social cohesion mark out the boundary between the normal and the deviant, reinforcing elements of control.

Blair's vision for social cohesion is summarised in his introduction to the Respect Action Plan: 'Stable families, and strong cohesive communities are ... the essential foundation within which individual potential is realised, quality of life maximised and our social and economic wellbeing secured' (Blair 2006:1). The plan's focus on children, youth and families reinforces the policy as a vision for the future. Indeed, it aims to "ensure that we all pass on decent values and standards of behaviour to our children' as well as to 'build trust, share values and agree what is acceptable behaviour' (Home Office 2006:3). The concepts of 'respect' and 'social cohesion' are tied together.

Pertinent to youth is the link between social cohesion and citizenship (Shukra et al. 2004:191). The emphasis on teaching citizenship (formally and informally) aims to ensure 'the induction of young people into the legal, moral and political arena of public life' (Crick 2000a:8). New Labour wants to create upstanding citizens who take their responsibilities to society seriously. As the Secretary of State for Education and Employment David Blunkett stated, 'We are seeking nothing less than the encouragement of active and responsible members of tomorrow's community ... bringing alive democracy at a time when cynicism and apathy is rife' (7 July 1999, quoted in Crick 2000:9). Starting from a negative premise of 'cynicism and apathy', citizenship education is part of the bid to 'remoralise society' (France 1996:37), and is part of the wider project to mould young people into obedient citizens.

Moreover, the connection between the political and the moral links citizenship with wider concerns about social exclusion and anti-social behaviour; citizenship education is aimed at those who 'feel alienated, disaffected, driven to, or open to, strong degrees of anti-social behaviour' (Crick 2000b:149). The over-riding assumption is that 'moral sensibility derives in part from political understanding; political apathy spawns 
moral apathy' (Hargreaves 1997, quoted by Citizenship Advisory Group 1998:10). Indeed, 'citizenship education is education for ... behaving and acting as a citizen ... it is not just knowledge of citizenship and civic society' (Citizenship Advisory Group 1998:13). In this context citizenship education has a moral imperative over and above political literacy. Active participation is twinned with citizenship education in New Labour's moral crusade. The Citizenship Advisory Group (1998:10) claims that 'recently the terms "good citizen" and "active citizen" have come back into currency'. Community involvement is one of the "necessary conditions of civil society and democracy' (ibid). Participation is seen as a way of bringing people together, instilling a sense of community and diverting young people from deviant activities.

Volunteering is emblematic of the type of participation encoded in the social cohesion paradigm, as a means of 'helping to build social capital', and of being 'of measurable benefit to local communities' (Russell 2005:6-7). For young people, it is a way that they can 'contribute to their communities' whilst building skills and improving employability (DfES 2005b:32). Volunteering blurs with citizenship education in the drive to reinvigorate democracy at a local level; 'there are particular opportunities to involve young people in shaping local services and as active citizens in local democracy' (Russell 2005:17).

The joint promotion of citizenship education and active participation aims to instil morality and prevent societal decay among the young. The Citizenship Advisory Group (1998:15) notes that, as well as political apathy, 'truancy, vandalism, random violence, premeditated crime and habitual drug-taking can be other indicators of youth alienation'. Youth Matters claims that busy young people 'are less likely to drift into trouble, cause a nuisance or commit crime' (DfES 2005b:5). This echoes the 'respectable fears' concerning the underclass (Jeffs 1997:155). At its crux is the 'widespread unease that the values necessary to support respect are becoming less widely held' (Home Office 2006:5).

Moral undertones beg the question of shared values assumed by citizenship education and the wider 'respect' agenda. Blair (2006:1) claims that there are 'values that almost everyone in this country shares - consideration for others, recognition that we all have responsibilities as well as rights, civility, and good manners'. Moreover, citizenship education aims to foster 'respect for law, justice, democracy, and nurture the common good' (Crick 2000a:8). Concepts such as 'common good' are used as if they are unproblematic, and without clear definition. The word 'community' is used in a nostalgic way, overlooking the reality that, rather than being places of consensus, communities often foster conflict and exclusion (Oliver 2005:38).

The concept of 'responsibility' is emblematic in the vision of social cohesion; social 'problems' are spoken about in terms of taking 'responsibility', cementing the shift towards personal culpability (France 1996:39). 'Responsibility' is conceived not only as a civic value, but also as an Aristotelian 'moral virtue' (Crick 2000a:10). Blair (2006:1) has stated, 'We need to take responsibility for ourselves, our children and our families, support those who want to do the same - and challenge those who will not'. 'Responsible' sums up New Labour's ideal citizens: hard working, moral, lawabiding, respecting the government and its priorities. Moreover, 'responsibility' can be used to silence dissent or criticism of the status quo.

'Cohesion' and 'responsibility' are benign ways of saying 'control' and 'consensus'. The formalisation of volunteering enshrined in the report of the Russell Commission (Russell 2005:6) and the Respect Action Plan (Home Office 2006:10) reinforces the 
creation of acceptable modes of volunteering in line with governmental aims of social cohesion. Moreover, the government has successfully criminalised non-criminal behaviour by creating a whole new category of deviance known as 'anti-social behaviour' (Grier and Thomas 2003:8). By reclassifying the deviant outside the realm of the British legal system it has given itself a legitimacy and mandate to control people's behaviour in the name of public security. Critics are silenced: 'Certain academics and civil libertarians say the provisions are ... incompatible with the European Convention on Human Rights. The Government does not accept that' (Home Office 1999).

Written rhetoric, as Stoler (2002:154) argues, has the power to re-define and create order. The written discourses of New Labour reconfigure reality, defining the deviant and legitimising courses of action. Emblems of control and cohesion are part of the same over-arching narrative and system of knowledge, which embodies 'specific understandings of the objects of governmental practice ... and stipulate suitable ways of managing them' (Inda 2005:8). The title Respect and Responsibility: Taking a Stand against Anti-Social Behaviour expresses this joint narrative (Home Office 2003). Whilst the ASBO symbolises New Labour's 'bad cop' side, discourses of citizenship, social cohesion and respect are the softer side; 'our aim is for a "something for something" society where we treat one another with respect and ... share responsibility for taking a stand against what is unacceptable' (ibid:6).

A wider ethical question arises for practitioners from the clearly moralised and negative backdrop to participation and citizenship. Within the New Labour citizenship paradigm, 'the youth worker is expected to pre-define the knowledge requirements of the young person' (Forrest 2005:96). Freire (1996:53) critiqued this 'banking style' of education for overlooking the importance of dialogue. An alternative approach is political education in the sense of developing critical awareness and reflecting on experiences (Shukra et al. 2004:192). Further implications regarding practice will be discussed in the final section.

\section{Consumption: the de-politicisation of participation?}

Participation can be used to divert, frustrate, and manipulate. (Smith 1981a:x)

Ferguson (1990) argues that the development apparatus in Lesotho is an 'anti-politics machine', depoliticising everything it touches. This shrouds political realities whilst simultaneously 'performing, almost unnoticed, its own pre-eminently political operation of expanding bureaucratic state power' (ibid:xv). The institutionalisation of the 'development problematic' has concrete political effects. Ferguson's framework can similarly be applied to New Labour's depoliticised construction of citizenship and participation. By reframing the idea of 'youth participation' in a de-politicised way, young people are re-constructed as passive consumers. This enhances the power and legitimacy of the government.

\section{Construction of the object}

The ideology of consumerism has transformed our ways of thinking about individuals and their identity. (Lewis et al. 2005:139)

New Labour constructs citizens as consumers, in line with its economic and social policies. The shift from welfarism towards monetarism has involved the state 
disengaging itself from the economy and allowing market forces increasing control (Mizen 2004:19). Yet even this act of de-politicisation is a political decision that has had concrete effects in the restructuring of social relations (ibid). At the same time, the media, a key arena for the social construction of citizenship, portrays citizens as self-interested and politically uninformed, only able to comment on their own lives; 'the news paints a picture in which citizens have experiences and feelings rather than opinions' (Lewis et al. 2005:136). This reinforces their role as consumers of politics rather than active, political agents. Political allegiance has morphed into brand loyalty (ibid:138).

The economic liminality of young people reinforces their portrayal as consumers and as non-productive economically in society (cf. Edwards 1996:48). They are 'preemployment' (Franklin and Franklin 1990:21). The link between volunteering and youth citizenship discussed in the previous section emphasises their association with unpaid work. Payment is in the form of accreditation and marketable skills (Smith 2005:86). The Russell Commission emphasises how 'the opportunity to improve skills and employability is a powerful incentive for young people to volunteer' (Russell 2005:18).

Volunteering (and other types of participation) is increasingly constructed through the model of consumption. The Russell Commission uses consumer terminology, discussing a 'menu of opportunity', with 'choice' available, alongside a 're-branding' of Millennium Volunteers and 'peer ratings' (Russell 2005:15). Incentivising volunteering has been criticised for overlooking the importance of relationships within youth work, focusing on 'reified notions of what can be given, earned and evaluated' (Wolfe 2005:60). Whereas traditionally youth work was a process of informal education and the development of identity through certain experiences, the focus has shifted to 'fostering employability and enabling (young people) to better manage the transition from school to the domestic, industrial and commercial niches that await them' (Jeffs and Smith 2006:29).

This focus on economic productivity could overshadow the deeper benefits for young people such as self esteem and friendship. In my own experience, a group who helped to plan youth conferences made the following comments about their highlights: 'seeing everything fall into place and being like, wow, we did that!', 'socialising and communicating different ideas to each other', and 'it was good to meet new people' (Ashcroft 2006:5-6). In addition, focusing on employable skills and consumption could under-estimate the barriers of social problems and poverty, which contribute to the marginalisation of many young people (Adams 2003:28). Not to mention the lack of vocational opportunities for young people post-16, an issue which was repeatedly raised by young people at a youth conference Croydon Youth Service held in 2005 (Ashcroft 2005:8).

The critique of the consumer model is not anti-materialistic idealism. The concern is not the ethics of the consumer model per se, but rather its suitability as a representation of citizenship and responsibility.

\section{The new orthodoxy and representations of truth}

The construction of citizens as consumers mirrors a corresponding representation of citizenship in New Labour discourse. Citizenship as consumption revolves around consultation, choice and formalisation, with passive connotations: 'consumers are seemingly apolitical and disengaged from community decision-making. They respond 
to the possibilities on display rather than setting the agenda' (Lewis et al. 2005:138). This circumscribes power to choice between products, or opting out. It echoes Schumpeter's model of democracy as 'the opportunity of accepting or refusing the men who are to rule' (Schumpeter 1976:284-285). New Labour is preoccupied with voting as an indicator of a healthy democracy. Turnout figures are cited as the main evidence for youth disengagement, and a mandate for encouraging youth participation. Yet voting is an ultimately passive activity, since it is just choosing between options.

Participation methods increasingly consult the individual on his/her preferences, rather than 'empowerment through collective association and ... community development' (Oliver 2005:39). Youth Matters has been criticised for encouraging participation that is characterised by 'more and more individual choices made in isolation' (Davies 2005a:24). Participation as 'helping people develop a strong collective voice' is sidelined (Commission on Poverty, Participation and Power 2000:10). Moreover, treating people experiencing poverty as consumers overlooks the fact that they 'have few choices and little bargaining power. To treat them simply as consumers does not work' (ibid:3).

Consultation leaves the power and agenda-setting with the authoritative body. Community representatives frequently complain that 'there is no level playing fieldthe power, reports, money, agenda and ground rules are all controlled by the people encouraging [us] to "participate" (Commission on Poverty, Participation and Power 2000:15). Consultation is the approach that institutionalised local authority participation has traditionally taken (Smith 1981b:18). Often consultation takes place after most of the work has been done, leaving little room for manoeuvre (ibid:19) A study into regeneration initiatives confirmed that agendas are often set in advance of community participation, and there was pressure to respond to these official agendas, thus sidelining other ideas (Anastacio et al. 2000).

This was certainly the case with the government's consultation on Youth Matters (DfES 2005a). Questions included: 'Would a card that gave you discounts and money to spend on activities encourage you to do more activities in your spare time?', and, 'We think young people who misbehave or commit crimes should not get these discounts and top-ups. What do you think?' Participants could tick agree, disagree, or not sure. Such questions offer little room for other ideas; arguably the government has decided its policy and wanted a youth mandate to make it look like it's 'what you asked for'.

Ideas of consumer choice take no account of disagreement, within communities or with the government. This reflects the orientation of New Labour towards consensus (discussed above). Young people are often misguidedly treated as a homogenous group, and youth workers can become confused about what young people really want (Powley and Lloyd 1987:3). Differences of opinion present a challenge for authorities who want the convenience of a unified view (Ananstacio et al. 2000). Only unified opinions actually spur voluntary and statutory bodies on to take action at the youth conferences I have been involved with. Issues reflecting more divergence are set aside, and not pursued any further. Even when the consultation agenda is more open and participative, there are always constraints affecting institutionalized participation. I have supported young people to plan youth consultation events, enabling them to decide the topics up for discussion, and invite the officials they want. The agenda is something that they feel strongly about or wish to discuss. Yet the organisation I work 
for is unwilling to fund conferences discussing issues that have been covered in recent events. Consequently ongoing or unresolved issues are not re-visited.

The consensus implied in this concept of participation can reinforce the status quo. As Merton (2005:32) notes, Youth Matters 'does not portray young people as constructive critics of the state and society'. Since the authorities hold the money and the power, these differing agendas are usually pushed aside. The Commission on Poverty, Participation and Power found that people experiencing poverty often face barriers to participation because of their different agenda (Commission on Poverty, Participation and Power 2000:19). By not opening the possibility of dissent and disagreement, the government's logic of agenda-setting is carried through.

Pre-defined choice and consultation point to an inherent passivity within the consumer model. The local government reforms aim to catalyse the rebirth of local democracy and civil society, yet the policies actually propose 'symbolic participation' rather than enhancing accountability (Chandler 2001:4). A division between the executive policymaking department and the representative side means that the reforms attempt to 'involve and create active citizens but none of them give those involved any greater control over policy making' (ibid:10). Chandler argues that this symbolises the move towards the 'therapeutic state', in which involvement is characterised by 'individual expression rather than collective decision-making' (ibid:11). The individualised nature of consumer citizenship is characterised by the 'collective expression of individual feelings' (ibid). Paradoxically, New Labour calls for people to become 'active citizens' through a passive notion of citizenship that is individualised, compartmentalised, and instigated from above.

\section{Defining the illegitimate}

The flip-side of the hegemonic representation of truth is the carving out of the illegitimate sphere. New Labour discourse has championed the consumer model of citizenship, yet it has ignored, devalued or even obstructed 'deviant' modes of participation. Deviant modes are instigated externally to official channels, and are more radical in their approach.

Direct action is the most emblematic of the deviant modes within the New Labour paradigm. The Stop the War Protests of 2003 were some of the largest protests ever seen in the UK. As an organic expression of social cohesion representing various faiths and ethnicities (Shukra et al. 2004:193), they were also notable for the involvement of children and young people. Newsround documented young people walking out of lessons to march, with 500 pupils protesting in Oxford alone (Newsround 2003a, 2003b and 2003d). This action was actively obstructed by the police and schools alike. Six pupils in Hove were suspended for two months for truanting (Newsround 2003a), and in Leicester 'extra police were on duty to try and stop kids leaving school', with teachers eventually locking the gates (Newsround 2003c). Direct action involves confrontation, and participation has, historically, been used by authorities to avoid, rather than provoke, confrontation (Smith 1981b:6).

There was no comment on the admirable passion shown by young people, because their actions were categorised as deviant rather than participatory. As the Citizenship Advisory Group (1998:10) argue, 'citizens must be equipped with the political skills needed to change laws in a peaceful and responsible manner'. This reinforces the prerogative of the authorities to define the sphere of the legitimate. The passion that many young people felt about the war reflects the 'fundamental repositioning of 
young people's political engagement towards ... single-issue campaigns and lifestyle politics' (Fahmy 2003:4). This global aspect of citizenship is largely ignored by New Labour, possibly because it does not enhance the government's legitimacy and distracts from the focus on a national agenda.

The 'problem' of political participation is that it is potentially subversive. In a youth work context it is recognised that 'the engagement of the [Youth] Service in issues of political education does bring both young people and youth workers into positions of ambiguity and dilemma' (Smith 1987b:22). To diminish its risky aspect, those in authority (youth workers and governments alike) naturally want to control it. This is done either by ignoring or obstructing what lies at the margins. Discussions have been held in my workplace about the extensive youth support for the British National Party (a UK political party associated with far-right views and racist ideology) within an area of the borough. A clear conflict lies between the Youth Service's policy of equal opportunities and anti-discriminatory practice, and the need to encourage participation and political consciousness. The way that this is often negotiated is to emphasise participation in the wider and de-politicised sense within a youth work context.

\section{The (political) effects of these representations}

The discussion so far has examined the objectification of the citizen as consumer, and the corresponding representations of citizenship and participation in the paradigm. I will now turn to the political effects. As Ferguson notes of the World Bank in Lesotho, the construction of a hegemonic problematic of 'development' de-politicises the question of poverty. As a result, the Bank can perform sensitive political operations 'under the cover of a neutral, technical mission to which no-one can object' (Ferguson 1990:256). Similarly, the New Labour discourse of 'participation' airbrushes questions of politics and power. This allows the government to perform political operations under the guise of 'empowering communities'.

The focus on the consumer model represents a shift towards the de-politicisation of citizenship, bypassing change and power. Analysing the Youth Service plans for their consideration of participation, Green and Sender (2005:49) found that although there was a general emphasis on getting young people involved and listening to their opinions, 'in none of the plans analysed was there any direct reference to the term "politics" or "political education". Similarly, Chandler (2001:13) concluded that by devolving no power or accountability to communities, the Local Government Reforms are 'more likely to institutionalise a network of passive individuals than create or empower active citizens'.

The government's ideas of political education focus on valuing existing structures, rather than discussing and challenging particular issues (Shukra et al. 2004:192). Proliferate models of youth participation aping the 'adult versions', such as youth councils, parliaments, and young mayors are favourable with government, and likewise with youth work managers who want to fulfil their targets for 'active participation'. Youth councils can just be another form of social control, inculturating young people into certain practices and norms (Killick 1987:23). Moreover, youth councils have a limited capacity to represent other young people, since their general point of reference is themselves (ibid). The UK Youth Parliament has been criticised for replicating the "now problematic adult political structures which resulted in high disaffection rates among 18 to 24 year olds' (Green and Sender 2005:47). Moreover, it struggles to involve marginal young people (ibid:46). 
Whatever form it takes, participation set up by adults in authority and named 'participation' immediately loses a sense of ownership by young people. Moreover, participation without control or relevance to people's lives is unlikely to dispel apathy or cynicism. As the Commission on Poverty, Participation and Power observed, people 'are prepared to put in energy and commitment where they had some control, and where the group's usefulness and relevance to daily life were crystal clear' (Commission on Poverty, Participation and Power 2000:40).

Smith (1981b) argues that we should not be surprised when participation instigated by the government reinforces the status quo. 'Real' participation involves re-distributing power. Since the authorities generally want to maintain their status, significant participation 'has to be wrested by the powerless rather than preferred by the powerful' (ibid:13). Unsurprisingly, young people are cynical about participation, because tokenism is the norm; "participation ... can operate as an echo, reflecting back the voices of the institutions organising the participation' (Commission on Poverty, Participation and Power 2000:44).

Youth conferences I have co-ordinated (alongside a youth team) have been met with cynicism both by young people and adults alike. Indeed, on the evaluation form we asked the young people, 'Do you think anything will change as a result of today?' Only four said yes. The rest said no (14) or maybe (22). When asked how the day could have been made better, the majority mentioned the question and answer session by key authority figures (such as police and teaching representatives). One young person commented: 'The panel did not answer the questions and seemed to look down on our questions even though we thought they were important.' Another delegate said, 'The panel could have directly answered all the questions, instead of us being told their stories. I also felt patronised' (Ashcroft 2005:12).

For change to happen, 'power must be shifted' (Commission on Poverty, Participation and Power 2000:44). A critical question for Freire (1996) is 'who does reality serve?' (Forrest 2005:95). Current conceptions of youth participation aim to 'domesticate and deceive the majority of the population, acting to reinforce the status quo' (ibid). New Labour's representations of reality, through discourses of anti-social behaviour and social cohesion, justify the need for control. The 'new orthodoxy' of participation is one facet of the agenda to control, contain, and develop young people. In the objectification of youth, New Labour discourses adhere to Foucault's definition of governing as 'systematic ways of thinking and acting that aim to shape, regulate or manage the comportment of others' (Inda 2005:1).

The de-politicisation of participation is therefore a natural assertion of the government's role; power is located in the creation of hegemonic discourse.

While New Labour politicians ... may talk of 'community' and 'spreading power to the citizens', they have ... presided over a growing centralisation of power, an erosion of local democracy ... [and] increasingly imposed statedefined objectives. (Jeffs and Smith 2006:33)

The discourses mask the real exercise of power, and this illusion makes it all the more tolerable for majority. As Foucault (1979a:86) observes, 'power is tolerable only if it masks a substantial part of itself'. 


\title{
Back to Foucault: young people as objects
}

Using Foucault's (1979a, 1979b and 1980) ideas and Ferguson's (1990) application as a framework, I have argued that New Labour has constructed hegemonic discourses of anti-social behaviour, cohesion and participation, amounting to the objectification of youth. This is a continuation of historical attempts to manage young people and their integration in society. Youth work is not exempt from this;

\begin{abstract}
glib, simplistic clichés which argue that youth work is about 'process not product' are dangerous nonsense ... All educational interventions relate ... to either the sort of individual or world that those undertaking the work wish to achieve. (Jeffs and Smith 2006:50)
\end{abstract}

Moreover, youth work is always treading a thin line between working in line with the hegemonic discourse or against it. Pragmatism has led managers to respond by 'trying to sell youth work to funders on the basis of its potential contribution to solving the latest moral panic or policy "problem"” (ibid:47). Youth work is entwined with ideas of deficit (ibid:52). Notions of deficit are especially critical in arenas such as 'empowerment' or 'participation', which claim to start from a positive outlook. Against this background, Foucault's concept of looking beyond and outside the discourse is crucial, since all youth participation is, in some way, a form of manipulation. This does not mean that participation is redundant. Rather, the power conferred in the youth worker's role needs to be recognised so that it can be handled sensitively (Powley and Lloyd 1987:3).

\section{Conclusion: implications for practitioners}

The way we interact with the world changes it, and determines the options for change. (Drinkwater 2003:64)

Many participatory projects can be classed as 'failures' because they do not empower, and fail to meet expectations. As mentioned above, practitioners end up fostering 'mildly humorous cynicism' as a result (Cooke and Kothari 2001:1). Yet, as Foucault suggests, one can 'reverse the problem and ask oneself what is served by the failure ... what is the use of these different phenomena that are continually being criticised' (Foucault 1979b:272). Although participation as a hegemonic discourse has a purpose for New Labour, it is still a valuable concept for youth work.

Over-emphasising discursive power can lead to the conclusion that everything is predetermined. Yet 'power must be analysed as something which circulates' (Kothari 2001:141). Hegemonic discourses have unintended consequences. Planned interventions can reap "powerful constellations of control that were never intended, but are all the more powerful for being "subjectless" (Ferguson 1990:19). As Foucault's (1979b) analysis of the prison illustrates, something intended to rehabilitate can end up reproducing delinquency (Ferguson 1990:19). Presumably this could work in the reverse so that positive outcomes are born of the intention to dominate.

One of my colleagues who works in a local housing estate set up a youth forum with an unexpected agenda. Local youth on the estate had received letters from his department threatening them with curfews and ASBOs for playing football on the estate during school holidays. The construction of young people as a source of disorder was directly confronting the vision of young people needing to be involved 
and empowered. The worker responded by supporting them to write an official complaint to the housing department. The result was a visit from the leading housing officer for ASBOs, and the policy was reviewed. These conflicting agendas for young people can become a locus for engaging them.

The challenge for youth and community workers is to approach hegemonic discourses self-critically and to work out how to use their power in a sensitive and open way. It also means recognising that discursive powers are not only circulating on a governmental level but on more localised levels (for example within youth culture and among youth workers themselves). Freire's (1996) approach of examining the power relationship between practitioner and young person, entering into dialogue, and encouraging critical thinking, is a vital model in this instance (Forrest 2005:95-97). As Pearce and Hallgarten (2000:25) claim, citizenship education should, above all, be the 'education of the critical spirit'.

Working in this manner requires self awareness of personal bias: 'we are all bound to seek out persons ... with whom we believe we can work and who want to undertake the activities which we think are the most valuable' (Twelvetrees 2002:79). Workers need to be open to young people's views disagreeing from their own (ibid:8). It means recognising the contradictions within the host organisation (Datta 2003:57), and being careful not to exploit people's enthusiasm or expect too much. There will always be conflicts of interest for youth workers to negotiate. The challenge is to work for the best of young people where possible; indeed youth work is defined by an 'emphasis on the needs of young people as young people rather than simply as members of a community' (Smith 1987:17). Without that focus it is easy for young people's needs to be 'assimilated into a more general consideration of community priorities' (ibid). It means allowing young people to participate on their own terms, and ensuring adults are ready to listen (Gordon and Crewe 1987:10-13).

This is where New Labour and youth workers diverge; whereas the government is concerned with young people as part of a wider community that is being objectified and managed, the youth worker is focused on young people in their own right. Notwithstanding the fluidity to this distinction, what is salient is the question of priorities within the consciousness of the worker. A challenge remains:

to empower without being paternalistic, to enable without being top-down, to eliminate structural constraints along with patterns of passivity, to find realistic options and organise practical action. (Thomas-Slayter 2001:12)

\section{References}

Adams, P. 2003. Social exclusion and citizenship in a global society Youth \& Policy 80, 22-32.

Ashcroft, R. 2005. What's Good? The Report. Croydon: Croydon Youth Service.

--------. 2006. Report on the Youth Conference: U Never Know. Croydon: Croydon Youth Service.

Anastacio, J., B. Gidley, L. Hart, M. Keith, M. Mayo and U. Kowarzik. 2000. Reflecting Realities: Participants' Perspectives on Integrated Communities and Sustainable Development. Bristol: Policy Press, for Joseph Rowntree Foundation.

Blair, T. 2006. Foreword. In Respect Action Plan. London: COI (Home Office). 
Chandler, D. 2001. Active citizens and the therapeutic state: The role of democratic participation in local government reform. Policy \& Politics 29, 3-14.

Citizenship Advisory Group. 1998. Education for Citizenship and the Teaching of Democracy in Schools. London: Qualification and Curriculum Authority.

Commission on Poverty, Participation and Power. 2000. Listen Hear: The Right to be Heard. London: The Policy Press; The UK Coalition against Poverty.

Cooke, B. and U. Kothari. 2001. The case for participation as tyranny. In Participation: The New Tyranny? (eds.) B. Cooke and U. Kothari, 1-15. London: Zed Books.

Crick, B. 2000a. Introduction. In Essays on Citizenship (ed.) B. Crick, 2-12. London: Continuum.

--------. 2000b. Presuppositions of citizenship education. In Essays on Citizenship (ed.) B. Crick, 147-162. London: Continuum.

Datta, C. 2003. Participation of the people. In Pathways to Participation: Reflections on PRA (eds.) A. Cornwall and G. Pratt, 54-60. Brighton: Institute for Development Studies.

Davies, B. 2005a. If youth matters, where is the youth work? Youth \& Policy 89, 2126.

2005b. Threatening youth revisited: Youth policies under New Labour. The

Encyclopaedia of Informal Education, available at www.infed.org/archives/bernard_davies/revisiting_threatening_youth.htm

DfES. 1982. Experience and Participation: Review Group on the Youth Service in England ('The Thompson Report'). London: Department of Education and Skills (DfES).

-------. 2005a. Somewhere to Go? Something to Do? Consultation Response Form. London: Department of Education and Skills (DfES).

-------. 2005b. Youth Matters. London: Department of Education and Skills (DfES).

Drinkwater, M. 2003. Reflections on participation and empowerment. In Pathways to Participation: Reflections on PRA (eds.) A. Cornwall and G. Pratt, 60-68. Brighton: Institute for Development Studies.

Edwards, M. 1996. Institutionalising children's participation in development. PLA Notes 25, 47-51.

Eyres, T. 2005. Whose Green Paper is it anyway? Youth \& Policy 89, 27-31.

Fahmy, E. 2003. A disconnected generation? Encouraging young people's political participation in the UK. Youth \& Policy 81, 1-18.

Ferguson, J. 1990. The Anti-Politics Machine. Cambridge: Cambridge University Press.

Flower, C., P. Mincher and S. Rimkus. 2000. Overview: Participatory processes in the north. PLA Notes 38, 14-18.

Forrest, D. 2005. What does Paulo Freire have to say about youth work? Youth \& Policy 89, 94-103.

Foucault, M. 1979a. History of Sexuality, Volume 1. London: Penguin. 
1979b. Discipline and Punish: The Birth of the Prison. New York: Vintage.

1980. Power/Knowledge: Selected Interviews and Other Writings 1972-1977 by Michel Foucault (ed.) C. Gordon. New York: Pantheon.

France, A. 1996. Youth and citizenship in the 1990s. Youth \& Policy 53, 28-41.

Franklin, A. and B. Franklin. 1990. Age and power. In Young People, Inequality and Youth Work (eds) T. Jeffs and M. Smith, 1-27. London: Macmillan Education.

Freire, P. 1996 [1970]. The Pedagogy of the Oppressed. London: Penguin.

Geddes, M. and M. Rust. 2000. Catching them young? Youth \& Policy 69, 42-60.

Gordon, C. 1980. Afterword. In Power/Knowledge: Selected Interviews and Other Writings 1972-1977 by Michel Foucault (ed.) C. Gordon, 229-259. New York: Pantheon.

Gordon, S and J. Crewe. 1987. Balancing acts. In Putting Participation into Practice (ed.) National Youth Bureau, 10-13. Leicester: National Youth Bureau.

Green, R. and H. Sender. 2005. Marginal inclusion: what is the future for the UK Youth Parliament? Youth \& Policy 87, 45-54.

Grier, A. and T. Thomas. 2003. 'A war for civilisation as we know it': some observations on tackling anti-social behaviour. Youth \& Policy 82, 1-14.

Hargreaves, D. 1997. The Mosaic Learning London: DEMOS,

Henkel, H. and R. Stirrat. 2001. Participation as spiritual duty; empowerment as secular subjection. In Participation: The New Tyranny? (eds) B. Cooke and U. Kothari, 170-183. London: Zed Books.

Home Office. 1999. Home Secretary urges Councils to use new powers to protect the vulnerable. Press release, 15 October.

--------. 2003. Respect and Responsibility: Tackling Anti-Social Behaviour (CM5778). London: TSO. 2006. Respect Action Plan. London: COI.

Inda, J. X. 2005. Analytics of the modern: an introduction. In Anthropologies of Modernity: Foucault, Governmentality and Life Politics (ed.) J.X. Inda, 1-20. Oxford: Blackwell.

James, W. 1999. Empowering ambiguities. In The Anthropology of Power: Empowerment and Disempowerment in Changing Structures (ed.) A. Cheater, 13-28. London: Routledge.

Jeffs, T. 1997. Changing their ways: youth work and the 'underclass' theory. In Youth, the Underclass and Social Exclusion (ed.) R. Macdonald, 153-167. London: Routledge.

Jeffs, T. and M. Smith. 1998. The problem of 'youth' for youth work. Youth \& Policy 62, 45-64. 2006. Where is Youth Matters taking us? Youth \& Policy 91, 23-41.

Killick, J. 1987. Youth participation-for them or for us? In Putting Participation into Practice (ed.) National Youth Bureau, 22-23. Leicester: National Youth Bureau. 
Kothari, U. 2001. Power, knowledge and social control in participatory development. In Participation: The New Tyranny? (eds) B. Cooke and U. Kothari, 139-151. London: Zed Books.

Lewis, L., S. Inthorn and K. Wahl-Jorgensen. 2005. Citizens or Consumers? Maidenhead: Open University Press.

Lloyd, T. 2006. Respect plan causes controversy. Young People Now 2006 (January), 9.

Merton, B. 2005. Youth matters. Youth \& Policy 89, 32-37.

Ministry of Education. 1960. The Youth Service in England and Wales ('The Albemarle Report'). London: HMSO.

Mizen, P. 2004. The Changing State of Youth. Basingstoke: Palgrave Macmillan.

National Youth Agency. 2006. Government's Respect Action Plan earns words of caution from the NYA. Young People Now 2006 (January), 18-24.

Nelson, N. and S. Wright. 1995. Participation and power. In Power and Participatory Development: Theory and Practice (eds) N. Nelson and S. Wright, 1-18. Brighton: Institute for Development Studies.

Newsround. 2003a. Pupils suspended after war protest. 15 March. http://news.bbc.co.uk/cbbcnews/hi/uk/newsid_28510000/2851177.stm

--------. 2003b. Police warn pupils about anti-war rally. 18 March. http://news.bbc.co.uk/cbbcnews/hi/world/newsid 2862000/2862375.stm

------- 2003c. Violence hits pupil war protests. 19 March. http://news.bbc.co.uk/cbbcnews/hi/uk/newsid 2865000/2865341.stm

--------. 2003d. More school children march against war. 20 March. http://news.bbc.co.uk/cbbcnews/hi/uk/newsid 2868000/2868775

Oliver, B. 2005. Youth matters: money matters; the role of the community and voluntary sector. Youth \& Policy 89, 37-43.

Pollard, C. 2003. Keeping kids on the straight and narrow. Policy Review 2, 11-12.

Powley, T. and T. Lloyd. 1987. Taking participation seriously. In Putting Participation into Practice (ed.) National Youth Bureau, 3-4. Leicester: National Youth Bureau.

Pretty, J. 2003. What have we learnt from participatory methods? In Pathways to Participation: Reflections on PRA (eds) A. Cornwall and G. Pratt, 170-177. Brighton: Institute for Development Studies.

Russell, I. M. 2005. Executive Summary of the Report of the Russell Commission. London: HMSO.

Schumpeter, J. 1976. Capitalism, Socialism and Democracy. London: Allen \& Unwin.

Shukra, K., L. Back, M. Keith, A. Khan and J. Solomos. 2004. Race, social cohesion and the changing politics of citizenship. London Review of Education 2(3), 187-195. 
Smith, D. 1987a. Participation: The youth work response. In Putting Participation into Practice (ed.) National Youth Bureau, 4-5. Leicester: National Youth Bureau.

1987b. Reshaping the Youth Service. Leicester: National Youth Bureau.

Smith, H. 2005. The year of the volunteer: Formalising the goodwill mountain. Youth \& Policy 89, 84-94.

Smith, L. 1981a. Introduction. In Deprivation, Participation and Community Action (eds) L. Smith and D. Jones, ix-1. London: Routledge \& Kegan Paul.

--------. 1981b. A model for development of public participation in local authority decision-making. In Deprivation, Participation and Community Action (eds) L. Smith and D. Jones, 1-32. London: Routledge \& Kegan Paul.

Stoler, A. 2002. Perceptions of protest: defining the dangerous in colonial Sumatra. In The Anthropology of Politics (ed.) J. Vincent, 153-171. Oxford: Blackwell.

Taylor, M. 1995. Community work and the state: the changing context of UK practice. In Community Empowerment: A Reader in Participation and Development (eds) C. Craig and M. Mayo, 99-112. London: Zed Books.

Thomas-Slayter, B. 2001. A brief history of participatory methodologies. In Power, Process and Participation: Tools for Change (eds) D. Rocheleau and B. Thomas-Slayter, 10-17. Brighton: Institute for Development Studies.

Twelvetrees, A. 2002. Community Work, $3^{\text {rd }}$ ed. Hampshire: Palgrave.

Wolfe, M. 2005. Youth Matters: a plan for development? Youth \& Policy 89, 59-64.

Wulff, H. 1995. Introducing youth culture in its own right: the state of the art and new possibilities. In Youth Cultures: A Cross-Cultural Perspective (eds) H. Wulff and A. Amit-Talai, 1-19. London: Routledge.

Yelvington, K. 1996. Flirting in the factory. Journal of the Royal Anthropological Institute 2, 313-333.

Young, B. 2005. The impact of Youth Matters on youth participation. Youth \& Policy 89, 70-75.

\section{About the author}

Rachel Ashcroft studied Social and Political Sciences and Theology at Cambridge University, before completing an MA in Applied Anthropology, Community and Youth Work at Goldsmiths. She is currently working for Croydon Youth Service as a Youth Participation Worker. Recent projects she has worked on have included youthled conferences and managing the Youth Opportunity Fund project. She can be reached at rachelashcroft@fish.co.uk 